Scientia Agricola

http://dx.doi.org/10.1590/0103-9016-2015-0259

Note

\title{
Infection process of Phakopsora gossypii in cotton leaves
}

\author{
Leonardo Araujo ${ }^{1}$, Antonia Mirian Nogueira Moura Guerra², Paulo Geraldo Berger², Fabrício Ávila Rodrigues ${ }^{1 *}$
}

${ }^{1}$ Federal University of Viçosa - Dept. of Plant Pathology, Campus Universitário, s/n - 36570-900 - Viçosa, MG Brazil.

${ }^{2}$ Federal University of Viçosa - Dept. of Plant Science. *Corresponding author <fabricio@ufv.br>

Edited by: Claudio Marcelo Gonçalves de Oliveira

\begin{abstract}
Tropical rust caused by the biotrophic fungus Phakopsora gossypii is an emerging disease in cotton that has caused significant yield losses of crop/cotton cultivated in Brazil. Considering the current importance of tropical rust and the need to obtain additional basic information about its causal agent to better control this disease, the present study aimed to determine the infection process of $P$. gossypii in cotton leaves using scanning electron microscopy (SEM). Thirty-day-old plants were inoculated with a suspension of $P$. gossypii uredospores, and leaf fragments were collected $42 \mathrm{~h}$ after inoculation (hai) as well as 20,25 and 35 days after inoculation (dai) for SEM observations. By 42 hai, the uredospores of $P$. gossypii had germinated and produced a germ tube and an appressorium that may directly penetrate the leaf cuticle. At 20 dai, closed uredia containing uredospores were observed on the abaxial leaf surface. At 25 dai, the uredia started to open and became fully open by 35 dai and contained many uredospores. By 25 dai, fungal hyphae were growing abundantly in the mesophyll next to the uredia that formed in the leaf fragments with total or partial removal of the epidermis. The results of the present study provide novel information regarding the infection process of $P$. gossypii in cotton leaves, which might be useful for the development of new and more effective strategies for tropical rust control.

Keywords: Gossypium hirsutum, biotrophic fungus, tropical rust, uredium
\end{abstract}

Received June 25, 2015
Accepted September 15, 2015

\section{Introduction}

Cotton (Gossypium hirsutum L.) is the most extensively cultivated fiber crop in the world and contributes to approximately $85 \%$ of raw materials to the textile industry (Pindikur et al., 2012). The major cotton production areas are located in the Brazilian savanna and the occurrence of diseases is among the factors that greatly decrease cotton quality and annual yield (Guerra et al., 2013; Kirkpatrick and Rothrock, 2001; Pindikur et al., 2012). Tropical rust caused by the biotrophic fungus Phakopsora gossypii (Arthur) Hiratsuka f. is an emerging disease in cotton that has caused significant yield losses of cotton cultivated in Brazil, India and Jamaica (Guerra et al., 2013; Pindikur et al., 2012). The main symptoms of tropical rust are ferruginous pustules that are found on the abaxial leaf epidermis. On reaching maturity, the uredia easily break the epidermis to release uredospores. The first symptoms of tropical rust appear on older leaves, and plants become prematurely defoliated as the disease develops (Kirkpatrick and Rothrock, 2001; Pindikur et al., 2012).

Tropical rust control has been achieved with the use of fungicides, which greatly increase production costs because resistant cotton cultivars are not yet available to growers (Kirkpatrick and Rothrock, 2001; Pindikur et al., 2012). Considering the current importance of tropical rust and the need to obtain additional basic information about its causal agent for the development of new and effective control strategies, this study aimed to determine the infection process of $P$. gossypii in cotton leaves using scanning electron microscopy (SEM).

\section{Materials and Methods}

Cotton seeds (cv. BRS Buriti) were surface sterilized in $10 \%(\mathrm{v} / \mathrm{v}) \mathrm{NaOCl}$ for $2 \mathrm{~min}$, rinsed in sterilized water for $3 \mathrm{~min}$ and germinated in autoclaved sand. Ten days after germination, three seedlings were transferred to plastic pots containing $5 \mathrm{~L}$ of a nutrient solution composed of $6.0 \mathrm{mM} \mathrm{KNO}{ }_{3} 1.0 \mathrm{mM} \mathrm{NH} \mathrm{H}_{2} \mathrm{PO}_{4^{\prime}}$ $2.0 \mathrm{mM} \mathrm{MgSO} \mathrm{M}_{4} \cdot 7 \mathrm{H}_{2} \mathrm{O}, 4.0 \mathrm{mM} \mathrm{Ca}\left(\mathrm{NO}_{3}\right)_{2}, 0.30 \mu \mathrm{M}$ $\mathrm{CuSO}_{4} .5 \mathrm{H}_{2} \mathrm{O}, 1.30 \mu \mathrm{M} \mathrm{ZnSO}_{4} .7 \mathrm{H}_{2} \mathrm{O}, 46.0 \mu \mathrm{M} \mathrm{H} \mathrm{HO}_{3}$ $12.6 \mu \mathrm{M} \mathrm{MnCl} .4 \mathrm{H}_{2} \mathrm{O}, 0.1 \mu \mathrm{M}\left(\mathrm{NH}_{4}\right)_{6} \mathrm{Mo}_{7} \mathrm{O}_{24} \cdot 4 \mathrm{H}_{2} \mathrm{O}, 45$ $\mu \mathrm{M} \mathrm{FeSO}{ }_{4} \cdot 7 \mathrm{H}_{2} \mathrm{O}$ and $25 \mu \mathrm{M}$ ethylenediaminetetraacetic acid di-sodium salt. The nutrient solution, with aeration, was changed every three days. The electrical conductivity and $\mathrm{pH}$ of the nutrient solution were checked daily. The $\mathrm{pH}$ was maintained at $\approx 5.5$ using $\mathrm{NaOH}$ or $\mathrm{HCl}$ (1 N) when needed.

Plants were inoculated with a suspension of $P$. gossypii uredospores $\left(2.5 \times 10^{5} \mathrm{~mL}^{-1}\right) 30$ days after transplanting (V4 growth stage) (30 mL per plant). The uredospores were applied as a fine mist to the abaxial leaf blades until runoff using an atomizer (model VL Airbrush, Chicago, USA). Immediately after inoculation, the plants were transferred to a growth chamber for 24 h (temperature of $25 \pm 2{ }^{\circ} \mathrm{C}$, relative humidity of $90 \pm$ $5 \%$ and photon flux density at a plant canopy height of approximately $825 \mu \mathrm{mol} \mathrm{m} \mathrm{m}^{-2} \mathrm{~s}^{-1}$ ). After this period, the plants were transferred to a greenhouse (temperature of $25 \pm 2{ }^{\circ} \mathrm{C}$ and relative humidity of $50 \pm 5 \%$ ) and maintained there until the end of the experiment. The maximum natural photon flux density at plant canopy height was approximately $975 \mu \mathrm{mol} \mathrm{m} \mathrm{m}^{-2} \mathrm{~s}^{-1}$. 
Leaves with tropical rust symptoms and signs of $P$. gossypii were collected and processed according to Rodrigues et al. (2014). A total of 25 to 30 leaf fragments $\mid \approx$ $25 \mathrm{~mm}^{2}$ ) were randomly collected $42 \mathrm{~h}$ after inoculation (hai) as well as 20,25 and 35 days after inoculation (dai). The leaf fragments were carefully transferred to glass vials containing $10 \mathrm{~mL}$ of a fixative composed of $3 \%(\mathrm{v} / \mathrm{v})$ glutaraldehyde and $2 \%$ paraformaldehyde $(\mathrm{v} / \mathrm{v})$ in $0.1 \mathrm{M}$ sodium cacodylate buffer $(\mathrm{pH}$ 7.2). The leaf fragments were stored at $4{ }^{\circ} \mathrm{C}$ for 10 days, washed with sodium cacodylate buffer $(0.1 \mathrm{M})$ and then postfixed with $1 \%$ $(\mathrm{w} / \mathrm{v})$ osmium tetroxide prepared in the same buffer for $1 \mathrm{~h}$ at room temperature. The leaf fragments were dehydrated in ethanol and subjected to critical point drying in $\mathrm{CO}_{2}$ (model CPD 030, Hatfield, PA., USA). The abaxial epidermis of some leaf fragments collected at 25 dai was carefully removed using adhesive tape to have sight of $P$. gossypii colonization. Four specimens from each leaf fragment were mounted on aluminum stubs, sputter coated with gold (model FDU 010, Hatfield, PA, USA), examined and photographed using a LEO SEM (model $1430 \mathrm{VP}$, Jena, Thuringia, Germany) operating at $10 \mathrm{kV}$ and with a working distance ranging from 10 to $30 \mathrm{~mm}$.

\section{Results and Discussion}

This study provides, to the best of the authors' knowledge, the first microscopic evidence of the infection process of $P$. gossypii in leaves of cotton plants. In the case of $P$. gossypii at 42 hai the uredospores germinated, produced a germ tube and an appressorium that might directly allow the fungus to penetrate the leaf cuticle (Figure 1A). According to Vittal et al. (2014), the early events of uredospore germination, appressorium formation, and penetration of P. pachyrhizi on the soybean leaf occurred by 24 hai. The formation of appressoria is a pivotal event that allows a number of fungi to penetrate the leaf cuticle and establish a successful infection in their hosts (Chang et al., 2014; Dean, 1997; Loehrer et al., 2014; Ludwig et al., 2014; Mendgen and Deising, 1993). Certain biotrophic and hemibiotrophic fungi, such as those causing powdery mildews and anthracnose, respectively, can directly penetrate the cuticle through the action of cutinases, but in most cases, the strong osmotic pressure exerted by the melanized or not appressoria becomes detrimental (Dean, 1997; Ludwig et al., 2014; Mendgen and Deising, 1993). Other biotrophic fungi such as those causing rust can penetrate their host indirectly by entering the leaf mesophyll through stomata (Dean, 1997; Mendgen and Deising, 1993). Edwards and Bonde (2011) observed that an appressorium of $P$. pachyrhizi penetrated the leaf of soybean plants using primarily mechanical force with the aid of digestive enzymes. Chang et al. (2014) and Loehrer et al. (2014) showed that the turgor pressure formed on the appressorium of $P$. pachyrhizi was independent of melanin biosynthesis due to the metabolic degradation of products, such as glycerol, inside the appressorium. In the present
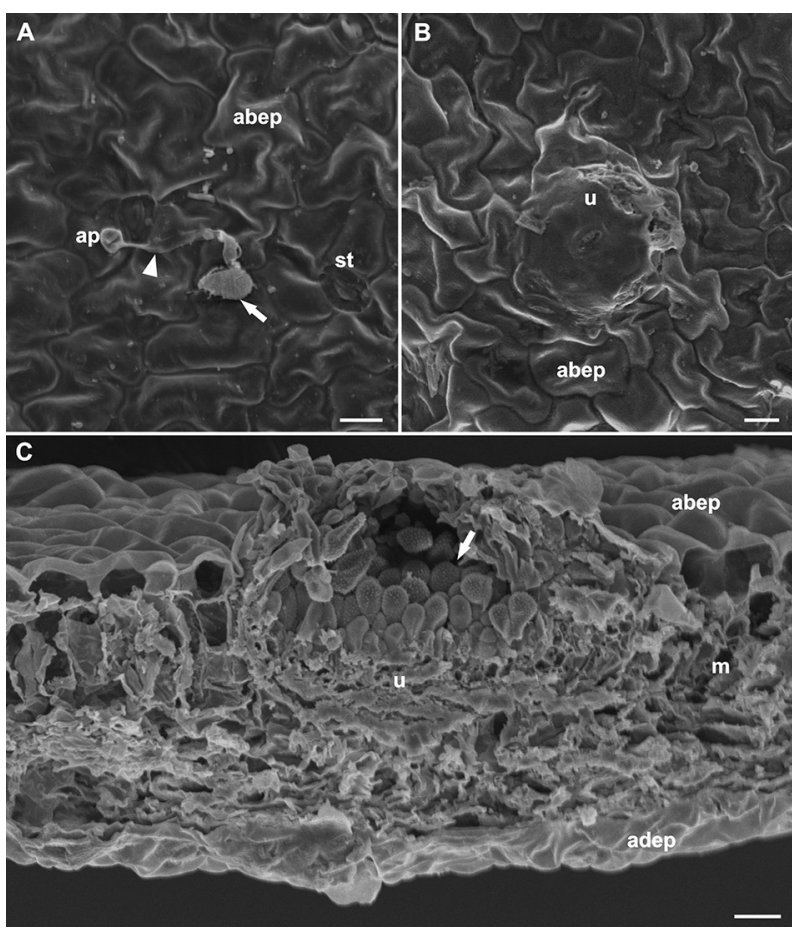

Figure 1 - Scanning electron micrographs of the abaxial leaf surface of cotton plants at $42 \mathrm{~h}(\mathrm{~A})$ and 20 days (B and $\mathrm{C}$ ) after inoculation with Phakopsora gossypii. (A), A uredospore (arrow) germinated, formed a germ tube (arrowhead) and produced an appressorium on the cotton leaf surface; (B), A closed uredium on the abaxial leaf surface; $(C)$ Cross-section of a leaf fragment showing a closed uredium with uredospores (arrows). Adaxial epidermis (adep), abaxial epidermis (abep), appressorium (ap), mesophyll (m), stomata (st) and uredium (u). Scale bars $=20 \mu \mathrm{m}$.

study, the events of pre-penetration of $P$. gossypii (uredospore germination until appressorium formation) on cotton plants appeared very similar to those observed for the interaction soybean-P. pachyrhizi.

At 20 dai, closed uredia containing uredospores were observed on the abaxial leaf surface (Figure $1 \mathrm{~B}$ and C). At 25 dai, the uredia started to open (Figure 2A, B and $\mathrm{C}$ ) and became fully open at 35 dai (mature) when it was possible to see many uredospores (Figure 2D, E and F). According to Guerra et al. (2013), the latent period of tropical rust ranges from 20 to 22 dai on cotton plants from cv. BRS Buriti. Medice et al. (2007) reported that the uredia of $P$. pachyrhizi on soybean leaves became completely open at 36 dai. Generally, the small and closed uredia of $P$. pachyrhizi on soybean leaves were associated with reduced Asian soybean rust symptoms because they produced fewer uredospores (Cruz et al., 2012; Medice et al., 2007; Vittal et al., 2014). The results from the present study strongly indicate that control managements against tropical rust, such as fungicides should be implemented up to a maximum of 20 days after the infection took place because from this time onwards, the uredia start to open and release the first uredospores. 

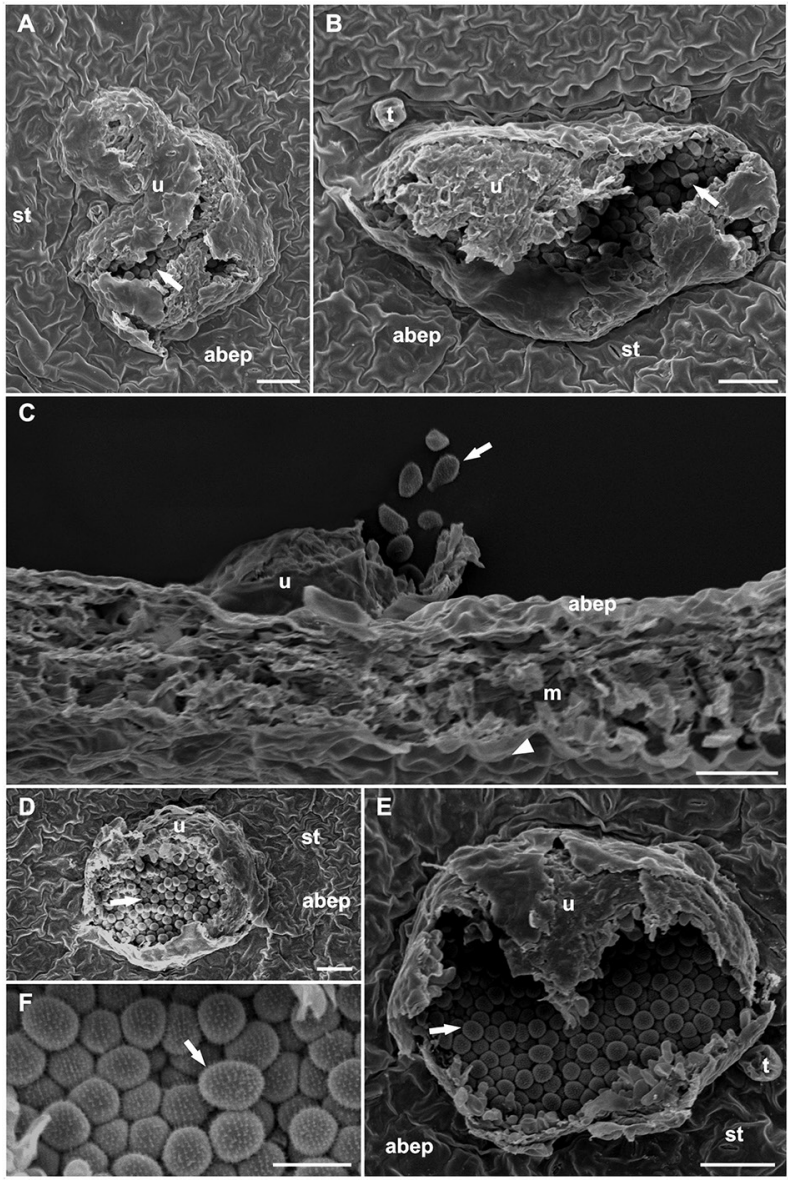

Figure 2 - Scanning electron micrographs of the abaxial leaf surface of cotton plants at 25 ( $A, B$ and $C$ ) and 35 days (D, E and $F$ ) after inoculation with Phakopsora gossypii. Uredia almost open (A and $B$ ) and fully opened (D and E) on the abaxial leaf surface; (C) Cross-section of a leaf fragment showing a uredium, not fully open, releasing uredospores (arrows); (F) Many uredospores (arrow) in an open uredium are shown at a higher magnification. Adaxial epidermis (arrowhead), abaxial epidermis (abep), mesophyll (m), stomata (st), trichome ( $\mathrm{t}$ ) and uredium (u). Scale bars $=50 \mu \mathrm{m}(\mathrm{A}$ to $E)$ and $20 \mu \mathrm{m}(\mathrm{F})$.

At 25 dai, the fungal hyphae grew abundantly in the mesophyll next to the uredia formed in the leaf fragments with total (Figure 3A and B) or partial (Figure 3C and D) removal of the epidermis. Based on SEM observations, Cruz et al. (2012) reported that the parenchyma cells in the soybean leaves next to the uredia of $P$. pachyrhizi were densely colonized by fungal hyphae. Vittal et al. (2014) reported that for a compatible soybean- $P$. pachyrhizi interaction, fungal hyphae need to massively colonize the mesophyll. Edwards and Bonde, (2011) used transmission electron microscopy and observed the hyphae and haustorial mother cells of $P$. pachyrhizi developed in soybean mesophyll between 14 and 21 dai. In the present study, the colonization standard of $P$. gossypii in cotton appeared similar to that of $P$. pachyrhizi in soybean.

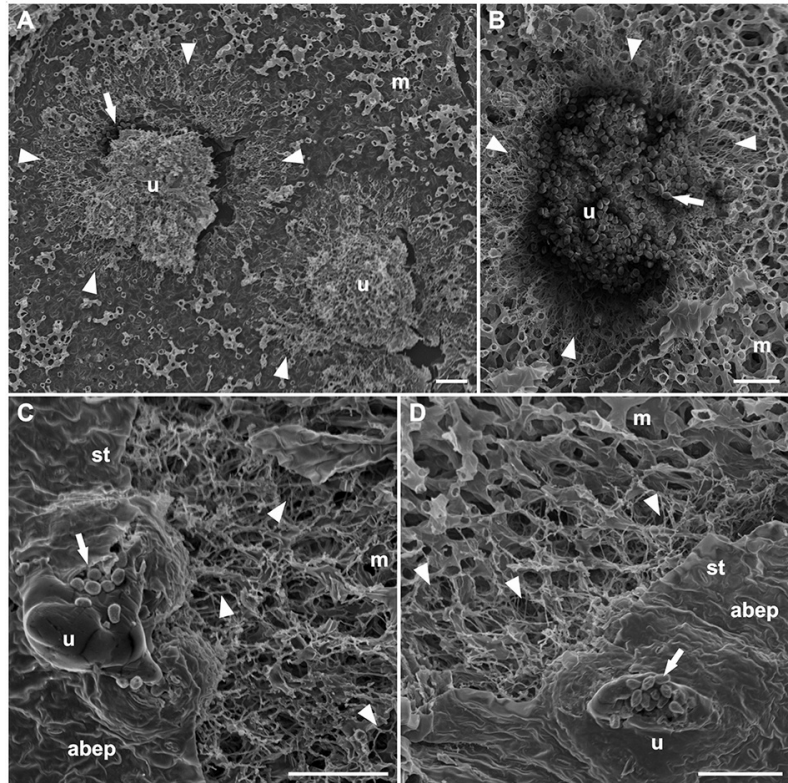

Figure 3 - Scanning electron micrographs of the abaxial leaf surface of cotton plants with total ( $A$ and $B$ ) and partial ( $C$ and $D$ ) removal of the epidermis at 25 days after inoculation with Phakopsora gossypii. Fungal hyphae grew abundantly (arrowheads) in the mesophyll next to the uredia. Arrows indicate uredospores in the uredia. Abaxial epidermis (abep), mesophyll (m), stomata (st) and uredium (u). Scale bars $=100 \mu \mathrm{m}$.

In conclusion, the results of the present study provide novel information regarding the infection process of $P$. gossypii in cotton leaves, which might be useful in the development of new and more effective strategies for tropical rust control.

\section{Acknowledgments}

The authors thank the 'Center for Microscopy and Microanalysis' of the Federal University of Viçosa for the use of equipment. Prof. Fabrício A. Rodrigues thanks the Brazilian National Council for Scientific and Technological Development (CNPq) for his fellowship. Dr. Leonardo Araujo was supported by CNPq (PDJ Scholarship - 502252/2013-8). This study was supported by grants from $\mathrm{CNPq}$ and the Minas Gerais State Foundation for Research Support (FAPEMIG).

\section{References}

Chang, H.X.; Miller, L.A.; Hartman, G.L. 2014. Melaninindependent accumulation of turgor pressure in appressoria of Phakopsora pachyrhizi. Phytopathology 104: 977-984.

Cruz, M.F.A.; Silva, L.F.; Rodrigues, F.A.; Araujo, J.M.; Barros, E.G. 2012. Silicon on the infection process of Phakopsora pachyrhizi on soybean leaflets. Pesquisa Agropecuária Brasileira 47: 142-145 (in Portuguese, with abstract in English).

Dean, R.A. 1997. Signal pathways and appressorium morphogenesis. Annual Review of Phytopathology 35: 211-234. 
Edwards, H.H.; Bonde, M.R. 2011. Penetration and establishment of Phakopsora pachyrhizi in soybean leaves as observed by transmission electron microscopy. Phytopathology 101: 894900.

Guerra, A.M.N.M.; Rodrigues, F.A.; Berger, P.G.; Barros, A.F.; Rodrigues, Y.C.; Lima, T.C. 2013. Cotton resistance to tropical rust mediated by silicon. Bragantia 72: 279-291 (in Portuguese, with abstract in English).

Kirkpatrick, T.L.; Rothrock, C.S. 2001. Compendium of Cotton Diseases. 2ed. American Phytopathological Society, Saint Paul, MN, USA.

Loehrer, M.; Botterweck, J.; Jahnke, J.; Mahlmann, D.M.; Gaetgens, J.; Oldiges, M.; Horbach, R.; Deising, H.; Schaffrath, U. 2014. In vivo assessment by Mach-Zehnder double-beam interferometry of the invasive force exerted by the Asian soybean rust fungus (Phakopsora pachyrhizi). New Phytologist 203: 620-631.

Ludwig, N.; Löhrer, M.; Hempel, M.; Mathea, S.; Schliebner, I.; Menzel, M.; Kiesow, A.; Schaffrath, U.; Deising, H.B.; Horbach, R. 2014. Melanin is not required for turgor generation but enhances cell-wall rigidity in appressoria of the corn pathogen Colletotrichum graminicola. Molecular Plant-Microbe Interactions 27: 315-327.
Medice, R.; Alves, E.; Assis, R.T.; Júnior, R.G.M.; Lopes, E.A.G.L. 2007. Essential oils used in the control of Asian soybean rust Phakopsora pachyrhizi Syd. \& P. Syd. Ciência e Agrotecnologia 31: 83-90 (in Portuguese, with abstract in English).

Mendgen, K.; Deising, H. 1993. Infection structures of fungal plant pathogens: a cytological and physiological evaluation. New Phytologist 124: 193-213.

Pindikur, S.S.; Rajanna, C.M.; Silva, J.A.T.; Doijode, S.; Sunkad, G. 2012. In vitro and in vivo evaluation of fungal toxicants for the control of cotton rust caused by Phakopsora gossypii (Arth.) Hirat. The Asian and Australasian Journal of Plant Science and Biotechnology 6: 7-13.

Rodrigues, F.A.; Silva, I.T.; Cruz, M.F.A.; Carré-Missio, V. 2014. The infection process of Pestalotiopsis longisetula leaf spot on strawberry leaves. Journal of Phytopathology 162: 690-692.

Vittal, R.; Paul, C.; Hill, C.B.; Hartman, G.L. 2014. Characterization and quantification of fungal colonization of Phakopsora pachyrhizi in soybean genotypes. Phytopathology 104: 86-94. 